\title{
Fuchs' dystrophy: Images taken with a mobile device
}

\section{Distrofia de Fuchs: imágenes con un dispositivo móvil}

\author{
Francisco Beltrán-Díaz de la Vega and Schenny Murra-Antón*
}

Asociación para Evitar la Ceguera en México I.A.P, Mexico City, Mexico

\begin{abstract}
Fuchs' endothelial dystrophy is a common disorder characterized by progressive corneal endothelial dysfunction. Clinically, central guttae are observed on Descemet's membrane and in late stages, corneal edema with epithelial bullae can be apparent. It may occur sporadically or be inherited with an autosomal dominant pattern. Usually, it affects women over 40 years old and is considered the most frequent cause for corneal transplantation worldwide. We present the case of a 59-year-old male with no significant history and with findings typical of Fuchs' endothelial dystrophy.
\end{abstract}

Keywords: Fuchs' endothelial dystrophy. Corneal endothelial cell loss. Corneal diseases. Corneal dystrophies, hereditary. Endothelium, corneal. Eye diseases.

\section{Resumen}

La distrofia endotelial de Fuchs es un trastorno común caracterizado por una disfunción progresiva del endotelio corneal. Clínicamente se observan guttae centrales en la membrana de Descemet, y en etapas tardías edema corneal con bullas epiteliales. Puede ocurrir esporádicamente o ser heredada con un patrón autosómico dominante. Afecta en general a mujeres mayores de 40 años y se considera la causa más común de trasplante de córnea en todo el mundo. Se presenta el caso de un paciente de 59 años, sin antecedentes de importancia, con hallazgos típicos de distrofia endotelial de Fuchs.

Palabras clave: Distrofia endotelial de Fuchs. Pérdida de células endoteliales corneales. Enfermedades corneales. Distrofias corneales hereditarias. Endotelio corneal. Enfermedades oculares.

A 59-year-old male indicated a history of fluctuating decreased vision in both eyes. Visual acuity after 3.5 hours of wakefulness was of 20/50 in the right eye and 20/60 in the left eye. The images show central corneal guttae with retro illumination (Fig. $1 \mathrm{~A}$ ) and with specular reflection (Fig. $1 \mathrm{~B}$ and $\mathrm{C}$ ). The photographs were captured using a smartphone (Model iPhone 8, Apple Inc. California, USA) on the slit lamp (Model SL9900, CSO, Florence, Italy). For capture, the brightness of the slit lamp was set to its maximum, the magnification was set to $10 \mathrm{X}$, the rear camera was placed in direct contact with the eyepiece and, while viewing the image on the smartphone screen, the focus was set by moving the slit lamp on the " $X$ " axis, using the smartphone autofocus as the final focus ${ }^{1-3}$. 


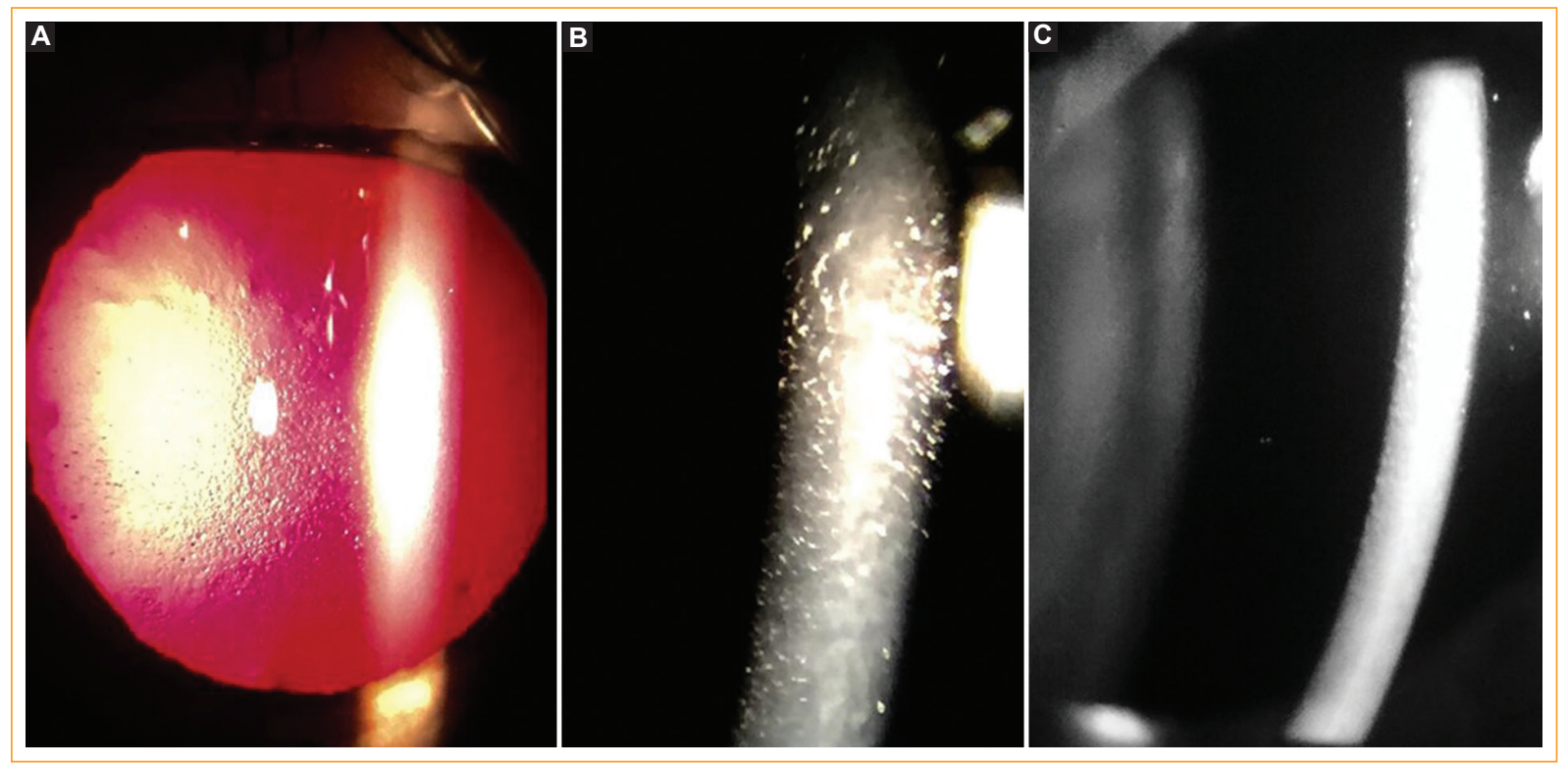

Figure 1. Slit-lamp photograph. A: central corneal guttae seen with retro illumination; B and C: corneal guttae seen with specular reflection.

\section{Conflicts of interest}

The authors report no conflicts of interest.

\section{Ethical disclosures}

Protection of human and animal subjects. The authors declare that no experiments were performed on humans or animals for this study.

Confidentiality of data. The authors declare that they have followed the protocols of their work center on the publication of patient data.
Right to privacy and informed consent. The authors have obtained the written informed consent of the patients or subjects mentioned in the article. The corresponding author is in possession of this document.

\section{References}

1. Soh Y, Kocaba V, Pinto M, Mehta J. Fuchs endothelial corneal dystrophy and corneal endothelial diseases: East meets West. Eye. 2019;34:427-41.

2. Gouranga Nanda G, Pankaj Alone D. Current understanding of the pathogenesis of Fuchs' endothelial corneal dystrophy. Mol Vis. 2019;25:295-310.

3. Matthaei M, Hribek A, Clahsen T, Bachmann B, Cursiefen C, Jun A Fuchs endothelial corneal dystrophy: clinical, genetic, pathophysiologic, and therapeutic aspects. Ann Rev Vis Sci. 2019;5:151-75. 